\title{
Energy Auditing of a Typical Residential Building in Ibadan Metropolis
}

\author{
*Diji, C.J and **Ganiyu, H. \\ * Ojoo Business Unit, Ibadan Electricity Distribution Company \\ ** Department of Mechanical Engineering, University of Ibadan, Ibadan
}

\begin{abstract}
An electricity audit of a building is the process whereby an energy manager survey and analyzes how energy is used in the building with the main objective of identifying opportunities for reducing the amount of energy used and ensuring that available energy is used efficiently.

This study reports the outcome of an electricity audit on a typical residential building in a major location of Ibadan metropolis. The audited building is a four - flat apartment where all the customers in the building have different tariff plans. Two of the customers labeled Customer A and B are metered, while the other two Customers labeled $C$ and $D$ are not metered.

The result of the audit showed that the metered customers were paying the actual estimated electricity bills, while the non-metered customers were over billed by over 30 and $80 \%$ respectively. The study concluded by recommending the metering of all residential apartments and the use of pre - paid meters as it not only stimulate demand but also is more effective in the electricity billing process

Key Words: Electricity Audit, Residential Building, Ibadan
\end{abstract}

\section{Introduction}

Electricity is the main energy source used in most building. Indeed, electricity is required for the operation of numerous appliances in all residential building. Residential or domestic load consists of lights, fans, and appliances like radios, heaters, electric irons, refrigerators, coolers, electric water heaters, washing machines, amongst others. The small residential electricity consumers may generally use all the light points simultaneously given a demand factor of unity. For big houses, the demand factor may be only around 0.5 .

The demand for electricity continues to rise as population grows. Electrical energy demand refers to the maximum amount of electrical energy that is being consumed at a giving time. It is necessary, for system planning and operation, to know the total electrical energy requirements and the duration of various loads in residential apartments. This is necessary to give residential consumers and building owners a proper sense of how much energy different appliances and activities consumed, because most people consistently overestimate the impact of less energy consuming appliances and less effective conservation activities and under estimate the impact of energy of more energy consuming appliances and more effective conservation activities (Kempton et.al 1985).

Understanding the way electricity is billed in residential apartments could sometimes seem very confusing, this is because unlike some other products, electrical energy cannot, in a practical sense, be stored. Rather, it needs to be generated and supplied as various equipments and home appliances require it. Day or night, the electricity utility provider must be able to meet the electricity requirements of its residential customers. The demand for electricity, and the flexibility needed to supply this electricity during peak times leads to "demand charges."

An energy survey and audit of buildings is the process by which a building is inspected and analyzed by an energy manager to determine how energy is used in it, with the goal of identifying opportunities for reducing the amount needed to operate the building while maintaining comfort level (Thumann and Young 2003).

This study reports the outcome of an energy survey and audit of a typical residential apartment in a typical residential area in Ibadan metropolis. The residential apartment is located at Onikoro area, Shasa, Ibadan. It is made up of a four flat apartment with each flat consisting of three bedroom, sitting room, dinning, two toilets, two bathrooms, kitchen, store, passage and corridor. It takes its source of electricity from Shasa 1 500KVA substation on Shasa 11KVA feeder.

The occupants of the apartment are on different electricity tariff plans. One of the occupants uses a single phase prepaid meter, another an analogue meter while the remaining two flats are on no meter. The study involves the interpretation and comparison of one of the monthly electricity bills of the different apartments in the building. The interpretation and comparison is done to make appropriate recommendations to the occupants of the building and the utility provider, the Power Holding Company of Nigeria (PHCN) on appropriate electricity consumption and billing for future electricity planning purposes. 
The study is divided into five sections. The first section includes the introduction; section two discusses extensively the concept of energy survey and auditing in buildings, while the third section elaborates the methodology used in conducting the study. Section four discusses the results of the study and section five concludes.

\section{ElectricityUse and Auditing in Buildings}

Electrical loads refer to the power consumed by a circuit and they are classified by tariff schedules into three major categories namely: industrial, commercial and residential loads. Industrial electricity customers usually engage in the manufacture of certain product or commodities and or convert given raw materials into partly processed or finished products basically different from the raw materials. The factories usually have a large number of motor, heaters, oven, presses air conditioning equipment and other electrical appliances. Assessing maximum electricity demands require a thorough knowledge of the industrial processes involved. Residential electricity consumers are typified by normal domestic utilization of electric energy for lighting, cooking, refrigeration and air conditioning, water heating, laundry and other miscellaneous applications. In assessing maximum demands of this category of loads, special attention should be paid to the air conditioning load and the standard of living of the occupier vis - a - vis the ability of the consumer to pay the electricity bills which may arise as a result of load and diversity factors assured in assessing the maximum demands and electricity requirements. Commercial electrical loads are all electrical loads that are neither residential nor industrial, usually involving small scale business outfits that are involved in providing various services.

An electricity audit is simply an audit or calculation of how much electricity is being used in the home and of where that electricity is going. An electricity audit can help to identify waste so that the causes of additional electricity use can be eliminated thereby reducing the expenditure on electricity in the home and reducing damages to the environment.

There are two different types of electricity audit. The first is simply a do - it - yourself audit; this involves the use of a calculator to find out how much energy each appliance and activity is using in order to identify where your money is going when you pay your electric bill. There are several online calculator tools that can be used for this purpose, thereby allowing the consumer to do is own electricity audit.

The second type of energy audit involves hiring a professional energy auditor to come to your home to identify where and how energy is being wasted. These energy professionals usual work for home improvement or building companies, and usually assist the residential consumer in identifying leaks and other areas of inefficient use of electricity. The outcome of their work is expected to assist the consumer to improve in efficient utilization of electricity and reduction in electricity costs in the home.

\subsection{Estimating Electricity Consumption and Cost of Domestic Appliances}

Electricity consumption is measured in kilowatt-hours $(\mathrm{kWh})$, and one $\mathrm{kWh}$ equals 1,000 watts of electricity used during one hour. To determine the total electricity consumed in the home by an electrical appliance over a given period of time, it is first important to determine the amount of power (watts) of the appliance. Manufacturers typically indicate the wattage on the back of the appliance. If the wattage is not given, look for the amperage (amps) and voltage (volts) listed on the appliance. The multiplication of the amperage with the voltage of the appliance will give the power (Watts) rating of the appliance.

To determine the electrical consumption of the appliance for a month, simply multiply the wattage times the number of hours the appliances is used and divide by 1000 to get the kWhs. For example if a 60 Watts bulb is used for a 5 hour period per day for a 30 days month; then the total electrical consumption will be $9 \mathrm{kWh}$.

The power consumed by each appliance during the year depends on, amongst other factors:

1. The average watts per hour consumed by the appliance when in active use. For many appliances, this is not the same as the rated power consumption of the appliance since most do not normally operate continuously at their rated energy consumption.

2. The number of hours in active use of each appliance per year.

3. The power consumed by the appliance (standby power) when it is not in active use.

4. Year in which it was sold

5. The market mix of the appliances sold in that year (size, technology, supplier)

6. The mean energy efficiency of those appliances both in operation and standby.

To calculate the cost of your electricity, whether for a particular appliance or other device, you need to know the rate of consumption and the price of the electricity. The former you can find either printed on the unit or in the manual. In addition to the rate of power usage, the duration of usage is part of the calculation. For the cost or the electric power, check your bill. The bill will show the price per power unit, the kilowatt-hour. That unit equals a consumption rate of 1,000 watts, in operation for one hour. 


\subsection{Electricity Metering and Billing}

An electric meter or energy meter is a device that measures the amount of electrical energy supplied to a residence or business. These are the customers of an electric utility. Utilities record the values measured by these meters to generate an invoice for the electricity consumed. The most common unit for measurement on the electricity meter is the kilowatt-hour which is equal to the amount of energy used by a load of one kilowatt over a period of one hour, or 3,600,000 joules.

Electrical metering is important because the performance of utilities at various points is judged by the global metering at grid points. For efficiency, therefore, the metering should be cascaded to the individual customer's premises. The accuracy of billing largely depends on the accuracy of metering and the number of metered premises. Thus there is the need to strive to provide meters to the customers not having meters and to repair or replace the faulty meters in the system.

Modern electricity meters operate by continuously measuring the instantaneous voltage (volts) and current (amperes) and findings the product of these to give instantaneous electrical power (watts) which is then integrated against time to give energy used (joules, kilowatt-hours etc). The meters fall into two basic categories: These are electromechanical and electronic meters.

Electricity billing is the process of converting the electric meter reading or estimation of the customer's consumption (and demand) to a bill using appropriate tariff. An electric bill is expected to indicate the information provided in Table 1 .

Table 1: Information on an Electricity Bill

\begin{tabular}{|c|c|c|}
\hline $\mathbf{S} / \mathbf{N}$ & INFORMATION & DETAILS \\
\hline \multirow{7}{*}{1.} & \multirow{7}{*}{ Customer Information } & Account Number \\
\hline & & Name \\
\hline & & Service Centre \\
\hline & & Type of Account \\
\hline & & Meter Status/dials \\
\hline & & Customer Type \\
\hline & & Average Daily consumption \\
\hline \multirow[t]{3}{*}{2.} & \multirow{3}{*}{ Description of Charge } & Energy charge (Where Applicable) \\
\hline & & Fixed Charge \\
\hline & & Meter Maintenance Charge \\
\hline \multirow{6}{*}{3.} & \multirow{6}{*}{ Transaction information } & Previous Balance \\
\hline & & Payments \\
\hline & & Adjustments \\
\hline & & Current Charges \\
\hline & & Value Added Tax \\
\hline & & Total Amount Due For Payment \\
\hline \multirow[t]{7}{*}{4.} & Other Required Information & LAR (Last Actual Reading) Date \\
\hline & & Date of Last Payment/Amount Paid \\
\hline & & Reconnection Fee Charges \\
\hline & & Tariff Rate for Account Type \\
\hline & & Due Date \\
\hline & & Read Date \\
\hline & & Tariff Code \\
\hline
\end{tabular}

Electricity bills are produced through three broad forms namely: meter reading, estimation and fixed consumption (direct) modes. Meter reading involves the subtraction of the previous reading from the present reading and the value obtained is used to bill the consumption of the customer, this mode of billing is the most convenient and appropriate form of billing.

Estimation mode of billing is used when there is no access to the customer premises and in situations in which the previous reading is observed to be higher than the present reading. The Fixed consumption mode of billing is used in situations where the bills are produced on fixed consumption; this mode is applied in situations where there is delayed meter installation, faulty meter or where the meter has been stolen.

\section{Research Methodology}

The study involved the energy survey and auditing of the selected area of research, which is the four flat apartment at the Onikoro area of Shasha area in Ibadan metropolis. The customers in the four flat as stated earlier have different tariff plans and their energy bills are estimated differently. Each of the flats consists of three bedroom, sitting room, dining room, two toilets, two bathrooms, kitchen, store, passage and corridor. 
The four customers have been designated as Customer A, B, C and D. Customer A uses a pre - paid meter; Customer B uses an analogue meter, while Customer $\mathrm{C}$ and $\mathrm{D}$ have no meters and their energy billing is currently done by fixed consumption mode.

The complete energy audit of the apartment was conducted over a two week period and involved collection of all necessary electrical appliances in each apartment. This included the identification of the electrical devices used, their types, models, current ratings, voltage ratings, cautions on them, input and output powers, amongst others. The audit also took into cognizance factors that could affect the effective distribution of electricity in the apartment such as technical and commercial losses, as well as unforeseen emergencies of extra load.

The general procedure used in the audit involved the following:

1. Facility and Utility Data Analysis

2. Walk through survey

3. Administration of questionnaires

4. Data processing and production of final report

It must be noted that in performing the audit, several of the tasks under the procedures stated above have to repeated, reduced in scope or even eliminated based on the findings of other tasks. Hence, an audit is often not a linear process, but is rather an iterative one.

\subsection{Facility and Utility Data Analysis}

In this step, the characteristics and patterns of electricity usein the building apartment was established. This involved the compilation and historical analysis of the utility bills of the apartment over a three months period i.e. from December 2011 to February, 2012. This was done to see if there is any seasonal and weather effects on the building electricity use. The monthly utility bills were obtained from the PHCN business unit in Ojoo and from established customer data for the same period.

\subsection{Walk through Survey}

During the audit exercise, a walk through survey was conducted to estimate the electrical load for each of the apartments and to identify potential energy saving measures that will eliminate wasteful usage of electricity. The tasks carried out during the walk through survey included:

I. Identifying the customer concerns and needs.

II. Checking the current operating and maintenance procedures.

III. Determining the existing operating conditions of major energy-use equipment (lighting, HVAC systems, etc.).

IV. Estimate the occupancy, equipment, and lighting (energy-use density and hours of operation).

\subsection{Field Questionnaires}

This was administered to each of the flats in the apartment to identify how electricity supply was received by each flat, the appliances used and the number of hours there was electricity availability during February 2012.

\subsection{Data Processing and Production of Final Report}

The results of the walk through survey and the administered questionnaires were used to estimate the connected load, maximum demand and demand factors of each flat and a full comparative energy use analysis of the building was carried out with the identification of energy losses.

\subsubsection{Connected load}

The connected load of a customer means the sum of the continuous rating of all the devices and outlet installed on all the distribution circuit. By calculating the Total Connected Load (TCL), it will be possible to estimate the TCL for a particular area and for determining the sizing of cables. The TCL also makes it possible to determine Maximum Demand (MD) for a customer or group of customers and provides the utility provider useful information for the purpose of meter deposit and utility bill.

\subsubsection{Maximum Demand (MD)}

This is the maximum power that a circuit is likely to draw at a certain time. Thus the maximum demand of a customer is always less than the connected load of a customer. The reason for this is that the connected loads are used intermittently and usually does not operate at their full electrical ratings. Also the maximum load demand cannot be calculated simply by adding the maximum demands of individual loads since the individual maximum demands occur at deferent times

The Maximum Demand is connected to the TCL by the Demand Factor (DF). The DF is the ratio of the MD of a system or part of a system, to the TCL on the system or part of the system under consideration. DF is always less than 1 (one). 


$$
\operatorname{DemandFactor}(D F)=\frac{\text { MaximumDemand }}{\text { TotalConnectedLoad }}
$$

\section{Results and Discussion}

Table 2 shows the preliminary results of the energy audit of the four apartments while Table 3 shows the estimated connected load for the residential apartment and Table 4 shows actual energy consumption and cost of electricity for the month of electricity and the electricity billing from the utility provider, the PHCN.

From the aforementioned tables, it is obvious that customer A with the pre- paid meters paid actual electricity bills and paid over 4 times more than the other customers in the apartment. Customer B, who is analogue metered and with a maximum demand of $2.9 \mathrm{~kW}$ was also properly billed as there is little or no disparity between the estimated cost of using electricity and the electricity billing from the utility company. In addition, customer B is obviously the most energy efficient occupant of the building.

Customer C and D who pay a fixed monthly charge are overbilled by over $30 \%$ and $80 \%$ respectively, due to non - availability of meters. This shows that fixed monthly charges will not be beneficial in the long run to most residential electricity consumers. It is better for all residential customers to be metered.

With regards to the Electricity Utility company. It is obvious that the use of pre - paid meters will stimulate consumption and bring more revenue to the company. The practice should be encouraged and sustained.

Table 2: Preliminary Results of Electricity Audit

\begin{tabular}{|c|c|c|c|c|c|}
\hline $\mathbf{S} / \mathbf{N}$ & LOCATION & Customer A & Customer B & Customer C & Customer D \\
\hline 1 & $\begin{array}{l}\text { Master } \\
\text { Room }\end{array}$ & $\begin{array}{l}\text { 1No } 60 \mathrm{w} \text { bulb } 1 \text { No } 65 \mathrm{w} \text { Standing } \\
\text { Fan } 1 \text { No } 64 \mathrm{w} \text { TV } 1 \text { No } 60 \mathrm{w} \\
\text { Laptop } 2 \text { Nos } 25 \mathrm{w} \text { Energy Bulb }\end{array}$ & $\begin{array}{l}\text { 1No 60w Bulb 1No } \\
65 w \text { Fan } 2 \text { Nos } 25 w \\
\text { Energy Bulb 1No } \\
\text { 180w Portable } \\
\text { Fridge }\end{array}$ & $\begin{array}{l}\text { 1No 100w Bulb } \\
1 \text { No } 55 \text { w Ceiling } \\
\text { Fan 2Nos } 25 \mathrm{w} \\
\text { Energy Bulb 1No } \\
45 \mathrm{w} \text { Standing Fan }\end{array}$ & $\begin{array}{l}\text { 1No 60w Bulb 1No } \\
55 \text { w Ceiling Fan } \\
\text { 2Nos 25w Energy } \\
\text { Bulb }\end{array}$ \\
\hline 2 & Master Toilet & Ino $100 \mathrm{w}$ Bulb & $\begin{array}{l}324 \mathrm{Ft} \text { Fluorescent } \\
\text { tube } 1 \mathrm{No} 40 \mathrm{w}\end{array}$ & 1No 60w Bulb & 1No 100w Bulb \\
\hline 3 & 2nd Room & $\begin{array}{l}\text { 1No } 100 \text { w Bulb } 1 \text { No } 55 \text { w } \\
\text { Standing Fan } 2 \text { Nos } 25 \text { w Energy } \\
\text { Bulb }\end{array}$ & $\begin{array}{l}\text { 1No 60w Bulb 1No } \\
60 \mathrm{w} \text { Laptop 1No } \\
\text { 55w Ceiling Fan } \\
\text { 2Nos 25w Energy } \\
\text { Bulb }\end{array}$ & $\begin{array}{l}\text { 1No 60w Bulb } \\
\text { 1No 65w Fan } \\
\text { 2Nos 25w Energy } \\
\text { Bulb }\end{array}$ & $\begin{array}{l}\text { 1No 60w Bulb 1No } \\
\text { 55w Standing Fan } \\
\text { 2Nos 25w Energy } \\
\text { Bulb }\end{array}$ \\
\hline 4 & 3rd Room & $\begin{array}{l}\text { 1No } 60 w \text { Bulb } 1 \text { No } 65 \text { w Fan } \\
2 \text { Nos } 25 \text { w Energy Bulb }\end{array}$ & $\begin{array}{l}\text { 1No 60w Bulb } 1 \text { No } \\
65 \mathrm{w} \text { Fan } 2 \text { Nos } 25 \mathrm{w} \\
\text { Energy Bulb }\end{array}$ & $\begin{array}{l}\text { 1No 60w Bulb } \\
\text { 1No 55w Ceiling } \\
\text { Fan 2Nos } 25 \mathrm{w} \\
\text { Energy Bulb }\end{array}$ & $\begin{array}{l}\text { 1No } 60 \mathrm{w} \text { Bulb } 2 \text { Nos } \\
25 \mathrm{w} \text { Energy Bulb }\end{array}$ \\
\hline 5 & 2nd Toilet & 1No 100w Bulb & 1No 60w Bulb & 1No 60w Bulb & 1No 100w Bulb \\
\hline 6 & Sitting Room & $\begin{array}{l}\text { 1No 100w T.V 1No 130w } \\
\text { Standing Fan 1No 190w DVD } \\
\text { Player 1No 25w DSTV Decoder } \\
\text { 4Nos 25w Energy Bulb 1No 40w } \\
\text { 32' 4Ft Fluorescent 1No 55w } \\
\text { Ceiling Fan 1No 2Hp } \\
\text { Airconditioning 1No 1000w } \\
\text { Stabilizer 1No 159w Computer } \\
\text { System (Monitor, System Unit, } \\
\text { Stabilizer \& UPS) 1No 35w Radio }\end{array}$ & $\begin{array}{l}\text { 1No 75w T.V 1No } \\
\text { 55w Ceiling Fan } \\
\text { 1No 25w DSTV } \\
\text { Decoder 4No 25w } \\
\text { Energy Bulb 1No } \\
\text { 1000w Stabilizer } \\
\text { 1No 25w Radio 1No } \\
\text { 40w 32' 4Ft } \\
\text { Fluorescent }\end{array}$ & $\begin{array}{l}\text { 1No 64w T.V 1No } \\
\text { 55w Ceiling Fan } \\
\text { 1No 190w DVD } \\
\text { Player 1No 35w } \\
\text { Radio 4Nos 25w } \\
\text { Energy Bulb 1No } \\
\text { 100w Bulb 1No } \\
\text { 1200w Pressing } \\
\text { Iron } \\
\end{array}$ & $\begin{array}{c}\text { 1No 100w T.V 1No } \\
\text { 130w Standing Fan } \\
\text { 1No 25w DSTV } \\
\text { Decoder 1No 40w } \\
\text { 32' } 4 \text { Ft Fluorescent } \\
\text { 1No 1000w } \\
\text { Stabilizer 1No } \\
\text { Laptop 80w 4Nos } \\
\text { 25w Energy Bulb }\end{array}$ \\
\hline 7 & $\begin{array}{l}\text { Dining } \\
\text { Room }\end{array}$ & $\begin{array}{l}\text { 2Nos 25w Energy Bulb 1No 60w } \\
\text { Bulb 1No 55w Ceiling Fan 1No } \\
\text { 150w Refrigerator } \\
\text { 1No1000w Stabilizer }\end{array}$ & $\begin{array}{l}\text { 2No 25w Energy } \\
\text { Bulb 1No 60w Bulb } \\
\text { 1No 65w Standing } \\
\text { Fan }\end{array}$ & $\begin{array}{l}\text { 2Nos 25w Energy } \\
\text { Bulb 1No 60w } \\
\text { Bulb 1No 45w } \\
\text { Standing Fan } \\
\end{array}$ & $\begin{array}{l}\text { 2No 25w Energy } \\
\text { Bulb 1No 100w Bulb } \\
\text { 1No 55w Ceiling Fan }\end{array}$ \\
\hline 8 & Kitchen & $\begin{array}{l}\text { 1No } 200 \text { w Freezer } 1 \text { No } 100 \mathrm{w} \\
\text { Bulb } 1 \text { No } 300 \text { w Fruit Extraction } \\
1 \text { No } 700 \text { w Toaster } 1 \text { No } 350 w \\
\text { Blender } 1 \text { No } 500 \text { w Stabilizer }\end{array}$ & $\begin{array}{l}\text { 1No 180w Freezer } \\
\text { 1No 100w Bulb } \\
\text { 1No 1000w } \\
\text { Stabilizer 1No } \\
\text { 1600w Electric } \\
\text { Kettle }\end{array}$ & $\begin{array}{l}\text { 1No 60w Bulb } \\
\text { 1No 300w Blender } \\
\text { 1No 1000w } \\
\text { Hotplate 1No } \\
\text { 1000w Boiling } \\
\text { Ring }\end{array}$ & $\begin{array}{l}\text { 1No 1000w Hotplate } \\
\text { 1No 100w Bulb 1No } \\
\text { 150w Refrigerator }\end{array}$ \\
\hline 9 & Passage & $\begin{array}{l}\text { 1No } 100 w \text { Bulb } 1 \text { No } 1200 w \\
\text { Pressing Iron }\end{array}$ & $\begin{array}{l}\text { 1No } 40 \mathrm{w} 2 \text { ' } 4 \mathrm{Ft} \\
\text { Fluorescent tube } \\
1 \text { No } 1200 \mathrm{w} \text { Pressing } \\
\text { iron }\end{array}$ & 1No 60w Bulb & $\begin{array}{l}\text { 1No } 60 \mathrm{w} \text { Bulb } 1 \text { No } \\
1000 \mathrm{w} \text { Pressing Iron }\end{array}$ \\
\hline 10 & Store & 1No 100w Bulb & 1No 60w Bulb & 1No 100w Bulb & 1No 100w Bulb \\
\hline 11 & Surrounding & 2 Nos $100 \mathrm{w}$ Bulb & 2Nos $100 \mathrm{w}$ Bulb & 2Nos $100 \mathrm{w}$ Bulb & 2Nos $100 \mathrm{w}$ Bulb \\
\hline
\end{tabular}


Table 3: Estimated Connected Load for Each Apartment

\begin{tabular}{|c|c|c|c|c|c|}
\hline S/N & LOCATION & $\begin{array}{c}\text { Customer A } \\
\text { (Watts) }\end{array}$ & $\begin{array}{c}\text { Customer B } \\
\text { (Watts) }\end{array}$ & $\begin{array}{c}\text { Customer C } \\
\text { (Watts) }\end{array}$ & $\begin{array}{c}\text { Customer D } \\
\text { (Watts) }\end{array}$ \\
\hline 1 & Master Room & 299 & $\mathbf{3 5 5}$ & $\mathbf{2 5 0}$ & $\mathbf{1 6 5}$ \\
\hline 2 & Master Toilet & $\mathbf{1 0 0}$ & $\mathbf{4 0}$ & $\mathbf{6 0}$ & $\mathbf{1 0 0}$ \\
\hline 3 & 2nd Room & $\mathbf{2 0 5}$ & $\mathbf{2 2 5}$ & $\mathbf{1 7 5}$ & $\mathbf{1 6 5}$ \\
\hline 4 & 3rd Room & $\mathbf{1 7 5}$ & $\mathbf{1 7 5}$ & $\mathbf{1 6 5}$ & $\mathbf{1 1 0}$ \\
\hline 5 & 2nd Toilet & $\mathbf{1 0 0}$ & $\mathbf{6 0}$ & $\mathbf{6 0}$ & $\mathbf{1 7 4 4}$ \\
\hline 6 & Sitting Room & $\mathbf{3 2 9 9}$ & $\mathbf{1 3 2 0}$ & $\mathbf{1 7 4 4}$ & $\mathbf{1 5 5}$ \\
\hline 7 & Dining Room & $\mathbf{1 3 1 5}$ & $\mathbf{1 7 5}$ & $\mathbf{1 5 5}$ & $\mathbf{2 3 6 0}$ \\
\hline 8 & Kitchen & $\mathbf{2 1 5 0}$ & $\mathbf{2 8 8 0}$ & $\mathbf{2 3 6 0}$ & $\mathbf{1 0 6 0}$ \\
\hline 9 & Passage & $\mathbf{2 2 0 0}$ & $\mathbf{1 2 4 0}$ & $\mathbf{6 0}$ & $\mathbf{6 0}$ \\
\hline 10 & Store & $\mathbf{1 0 0}$ & $\mathbf{6 0}$ & $\mathbf{6 0}$ & $\mathbf{2 0 0}$ \\
\hline 11 & Surrounding & $\mathbf{2 0 0}$ & $\mathbf{2 0 0}$ & $\mathbf{2 0 0}$ & $\mathbf{5 , 2 8 9}$ \\
\hline & TOTAL & $\mathbf{1 0 , 1 4 3}$ & $\mathbf{6 , 7 3 0}$ & & \\
\hline
\end{tabular}

Table 4: Actual Energy Consumed and Cost of Electricity Supplied

\begin{tabular}{|c|c|c|c|c|c|}
\hline $\mathbf{S} / \mathbf{N}$ & ITEM & Customer A & Customer B & Customer C & Customer D \\
\hline 1. & Connected Load (kW) & 10.14 & 6.73 & 5.29 & 4.68 \\
\hline 2. & Maximum demand (kW) & 3.3 & 2.88 & 2.36 & 1.27 \\
\hline 3. & Demand Factor & $\mathbf{0 . 3 3}$ & 0.43 & 0.45 & 0.36 \\
\hline 3. & Total Energy Consumed(kWh) & 610.23 & 176.97 & 170 & 134.01 \\
\hline 4. & Cost of Energy consumed ( & 4,342 & $1,291.88$ & $1,240.93$ & 978.27 \\
\hline 5. & $\begin{array}{l}\text { Energy Billing by PHCN for February, } \\
2012 \text { (\#) }\end{array}$ & & $1,301.04$ & 1,825 & $\mathbf{1 , 8 2 5}$ \\
\hline
\end{tabular}

\section{Conclusion}

The paper examined the outcome of an electricity audit on four customers on different tariff plans in a typical residential building in Ibadan metropolis. It is the conclusion of the study that the use of fixed charges for electricity billing is not favourable to residential consumers of electricity and the use of pre - paid meters will obviously stimulate electricity demand and consumption.

\section{References}

[1]. Electric Power Research Institute (1993) - Reduction cost by understanding your bill.

[2]. Ezeruigbo E. N (2001) - AT\&C Loss reduction India Experience

[3]. Osideide, A. A. (2011) - Strategic electricity marketing Activities in distribution companies of Nigeria

[4]. PHCN(2011) - Commercial instruction manuals

[5]. Taylor Francis Group LLC, (2006) - Handbook of energy efficiency and renewable energy 